\title{
PETER EISENMAN, OR HOW TO ELIMINATE WHAT ONE BECOMES
}

\section{A B S T R A C T}

Peter Eisenman is the Icarus of post-avant-garde architecture and has numerous highly regarded, controversial built structures to his name - such as the Memorial to the Murdered Jews of Europe in Berlin and the Ciudad de la Cultura de Galicia in Santiago de Compostela. How to eliminate what one becomes this is one way of summarizing one of the most decisive features of Eisenman's architectural praxis: the disappearance of the author. Displaying his disdain for individual style in the arts, Eisenman regularly threw Michel Foucault's question "what is an author?" into debates on architecture. However, the death of the author - "la mort de l'auteur" first proposed by Roland Barthes - was not an end in itself for Eisenman. For it is only the follow-up question "what is critique?"“2 that illuminates the role of the elimination of the author in the negativity aesthetics of Eisenman's architectural praxis: it is the dialectics of the critique of reason and epistemology. In that sense, Eisenman's theory of architecture constitutes an important - if not uncontroversial contribution to critical architectural philosophy. 


\section{AMOR INTELLECTUALIS DIABOLI}

No-one has more ruthlessly opposed the cult of the author's name and the belief in individual styles as Eisenman; yet, at the same time, he has sought in countless publications to establish the very identity whose demise he had previously encouraged with his freely fluctuating significants. "Why Peter Eisenman Writes Such Good Books"3 was Jacques Derrida's title for his enquiry into the author without handwriting, the stylist without a style. It was not by chance that Derrida made a connection between Eisenman and another author who claimed to have a "twofold provenance, as it were from the top and bottom rungs on the ladder of life, both décadent and beginning." "That author was Friedrich Nietzsche, who ended his game of identity and difference with a willful, intellectual short circuit. He preceded his autobiographical book Ecce Homo with the words "How to become What You Are." At around the same time, during his last autumn, Nietzsche also claimed to have twice attended his own funeral "as lightly clad as possible." 5 One funeral was that of the Italian General di Robilant, the other was that of the architect Alessandro Antonelli, who had designed the most audacious building in Italy at the time, the Mole Antonelliana, and, as such, served as an alter ego for Nietzsche.

"The End of the Classical: The End of the Beginning, the End of the End" is the title of one of the various texts in which Eisenman shows that he was not only always willing to embark on escalation and excess, but just as willing to use Nietzschean double negatives: "I'm not interested in beauty. I'm interested in terror," ${ }^{7}$ as he once put it in the fashion magazine, Vanity Fair, in the days when terror was still acceptable as an aesthetic principle.

Eisenman's paradigmatic elimination of the author is established in a number of dwelling houses he designed in the 1970s and 1980s which—with their radical conceptualism and immense aesthetic impact - aroused keen interest amongst architects, which even the classicists were barely able to conceal behind their public outrage. Despite their relatively modest dimensions, it is impossible not to now see Eisenman's residential house designs as icons of post-avant-garde architecture, starting with House I (1967-68) and continuing by way of House 11a (1978) right through to the Guardiola House (1988) — with pride of place going to House VI (1975).

These houses owe their appearance to quasi-automatic, formal design processes. Without exception, all these houses basically stem from the same, only marginally varied cuboid form, which is subjected to the simplest formal strategies of decomposition, that is to say, sections, divisions, subtractions and 
other modes of transformation. It must have come as a shock to many that the demise of the author in architecture also meant that nothing could be taken for granted any longer. And with the onset of serialization and processualization, architecture appeared to have succumbed to a soulless automatism. These designs were accompanied not only by pages of tedious protocols, ${ }^{8}$ but also by seemingly endless sequences of diagrams that were solely intended to prove the logical rigor of the processes whereby the architectural design - untainted by individual sensibilities - was exclusively beholden to its own syntax, that is to say, a grammar of signs and, hence, pure textuality.

However, it would be to misconstrue Eisenman's intentions if the disappearance of the author were to be understood merely as an ironic, intellectual game between author and work or as a superficial flirtation with travesty or camouflage. On the contrary, the disappearance of the author is one of the main cornerstones of Eisenman's specific dialectics of critique of reason and epistemology, or in other words, of Eisenman's amor intellectualis diaboli. According to Theodor W. Adorno and Max Horkheimer this includes "the joy of defeating civilization with its own weapons." It is only his critique of reason and his praxis of epistemology that localize Eisenman in the cultural history of the twentieth century, equidistant from the Modernist avant-garde, Postmodernism, and Deconstructivism, but above all Jacques Derrida's aesthetics of supplementarity. Eisenman's experimental aesthetics are neither a utopian-avant-garde triumph over dominant reason, nor are they-in a Poststructuralist sense - a subversive degradation of reason: they are "an instance of a critique of reason founded in experience." ${ }^{10}$

\section{CRITIQUE AND ECSTASY}

Eisenman's freemasonry of intelligence first culminated in his "Notes on Conceptual Architecture" of 1970. These consist of four pages with no text as such but just fifteen footnotes. With characteristic intellectual vigor Eisenman has reduced his authorship to a set of references to newspaper articles and books on the subject of aesthetic minimalism and conceptual art. However, the very attempt to do away with the irrationalism that is inherent in all authorship and the concomitant close ties between a work and its author, turned-due to the pure indexicality of the signs - into a new hermeticism. By choosing not to make any form of aesthetic impact, it seemed that right at the outset of his career Eisenman might be maneuvering himself into the cul-de-sac of autonomous conceptual art. The enacted nihilism of the "Notes on Conceptual Architecture" revealed all too clearly Eisenman's idealistic longings; an aesthetic fundamentalism shone through in the terror of theory. 
From the outset-and not entirely incomprehensibly-Eisenman's intellectualism was met with a deep-seated mistrust. This was mainly directed at Eisenman's determination to reduce the design process to a pure logic of relations. Some critics saw this as an acceleration of the processes of objectification and reification in the spirit of a positivist-mechanistic concept of Modernism, whereas others believed that Eisenman's formalized desemanticization and syntacticization were still imbued with hidden residues of iconography and inadvertent semantics. However, both groups, who were either in thrall to the categorizations of a Neo-Marxist critique of Modernism or to the critics who had signed up to the Postmodern linguistic turn, may be countered with the fact that - paradoxically but logically enough — precisely where Eisenman favors a syntactic-formal rather than a semantic-expressive approach, his own amor intellectualis diaboli comes to light less in his intellectualism than in the ecstatic aspects of his work.

Specifically, this is about the moment when Eisenman's design process turns from linear, rigorously logical procedures toward the labyrinthine and figurative-grotesque. With their linearistic process of evolution Eisenman's series of dwelling houses embody the real watershed in his work. The basis of this is the performative, linear design process wherein every step arises logically from the previous step but also questions that previous step and is negated as a normative force by every subsequent step. In terms of the logic of its specific evolution, each step is simultaneously a source of constructive affirmation and a source of critical negation. By excluding any subjective influence of his own, Eisenman takes this process to an extreme, to the point where each subsequent step leads to the collapse of the established order, where reason has escalated to its own limits and switches into self-negation, and linearity and processuality mutate into a synoptic simultaneity of forms, that is to say, into an indecipherable concentration of intersecting and interlinking lines, planes, and volumes. At the point of excess the processuality that had been following a rigorous, abstract logic suddenly turns into a Babylonianlabyrinthine confusion of forms.

It is therefore evident that, unlike architectural Deconstructivism, Eisenman's architectural praxis is about taking rationalism to its own extremes and not, on the face of things, about subverting it. At its highpoint, the terror of theory finds itself transformed into the unfathomably grotesque and labyrinthine, such that the clarity of linear, steadily advancing processuality switches into a bewildering simultaneity of forms, and heightened intellectualism turns into physiological psychology. 


\section{EXCESSIVE RATIONALITY}

Eisenman, as a proponent of the death of the author, only partially takes up Barthes' suggested transformation of the modern author into a Postmodern scriptor, that is to say, that architecture as composition should become architecture as text. In fact Eisenman's architectural theory, with its negativityaesthetics, is peculiarly at odds with Poststructuralist aesthetics. In open opposition to Derrida's aesthetics of supplementarity, which is posited on free, associative ideas that subversively undermine the system, Eisenman loves systems and consequences. For his technique of the ecstasy of rationality does not stop at the transition from individual composition to self-writing textuality. Eisenman is certainly not one of Foucault's founders of discursivity. In contrast to Derrida's free associations, which seem to be in keeping with an ideal of human creativity, Eisenman rates the impartiality of the intellect higher than intuition and he intensifies the intellectualistic, scientistic principle to the point of annihilation. That is to say, he drives logical process forward to the point where strictly logical seriality tips over into labyrinthine-grotesque, spatial figures. As the system collapses, the conceptual becomes figurative and figurative-labyrinthine structures turn into psychologism.

It is precisely at this juncture that Eisenman's notion of the end of the author also marks the end of the hermeneutic phantom and, consequently, the end of the work as intentional material imbued with a symbolic charge by the author. The work is no longer an expression or a likeness of the ideality invested in the material, but is solely determined by the supra-personal process of writing as a performative act, during the course of which architecture turns into textuality and textuality becomes "grotext."

By engaging with the notion of the grotesque, Eisenman has tapped conceptually into one of the most intriguing forms of aesthetic articulation. Following the discovery of the domus aurea in Rome in the late fifteenth century, the grotesque wall paintings found there were admired not for their specific expressivity, but for their depictions of "monstrosities . . botched together from a variety of limbs," "11 which are not likenesses in the usual sense, nor identifiable as anything else. They can be described as instances of varietá e stravaganza or of terribilitá e capriccio, that is to say, variety and extravagance or awfulness and caprice. Giorgio Vasari described them as "a kind of free and humorous picture." 12 Grotesqueries may also be unconstrained in their libertinaggio, which could be translated here as salaciousness, and as such have roots in repressed human drives, that is to say, in our psychological make-up. This lack of constraint is less evident in the sheer force of their images, which breaks 
all the formal laws of painting, than in the way that repressed human nature resurfaces, with all its impulsive vigor.

The enthusiasm for grotesqueries during the High Renaissance can be explained by the structural changes that were under way in aesthetics. In face of the rationalization of cultural life, repressed drives bubble in a Freudian manner to the surface in the free figurations of grotesqueries. As opposed to Derrida's Deconstructivism, it is here that the basis of the negativityaesthetics of Eisenman's architectural praxis looms into view. In Modernity aesthetic praxis is specifically not a subversion of rationalism, but an ecstatic transgression. Its aim is not destruction, but cognition. And it is here, in the shape of the grotesque, that Eisenman's epistemological approach culminates in the aesthetic duality of a critique of reason and epistemology.

On the fringes of rationalism, as it were at the tipping point into the grotesque, it may be said that, for Eisenman, his own radically liberating critique of reason is only possible through his logical pursuit of reason. And this is at the heart of the affinity of Eisenman's thinking with Adorno's aesthetic theory. For, in Adorno's view, "modern art is questionable not when it goes too far . . . but when it does not go far enough." ${ }^{13}$ Aesthetic praxis in modern art is only ever productive when it goes to extremes, not when it merely communicates. "L'eccesso è sempre portatore di conoscenze" 14 —Excess is the vehicle of cognition: with this insight, Manfredo Tafuri summed up the epistemologically critical components in Eisenman's apocalyptic-labyrinthine design processes.

\section{THE UNCANNY AND THE EXALTED}

Surely no other contemporary architect has taken a more radical approach to the myth. For what does the elimination of the author mean if not a reversal of the classical creator, the demiurge, who-as the archetypal image of an architect — deploys his almost superhuman will and strength to form the world from out of primal chaos by separating reason, ethics, and aesthetics from his Dionysian drives and impulses? But Eisenman's performativity, as a negative myth, culminates in the reverse procedure. And this leads to an architecture that, as a concrete, clearly identifiable object, enters into the realms of the labyrinthine and grotesque. And this makes it possible to define the aspect that is crucial to Eisenman's critical architectural praxis. It consists in the fact that he not only radicalizes the cognitive processes inherited from Modernism by taking them to extremes but, in his pursuit of excess, he pushes the rationalism that is inherent in Modernism beyond its own limits and, at the point where 
its tips into the labyrinthine-grotesque and figurative, drives it back to a point before its own fixed, rational beginnings. Eisenman's rational processes are diabolical, almost apocalyptic, insofar as through them enlightened reason arrives, in a Nietzschean manner, at a "fundamental sense of the uncanny and exalted," ${ }^{15}$ which in turn sees intellectualism switching into a psychologicalphysiological mode.

In any attempt to locate Eisenman in the architectural history of the twentieth century, it is essential to recognize that, with his diagrammatic, ultimately ecstatic design processes, he did away with the dualism of intellectual and sensory cognition, that legacy of Enlightenment aesthetics that still held sway over Modernism. At the ecstatic tipping point, sensory experience is placed after, not before rational processes: it is the result of these processes. Eisenman thus dissolves the dialectics of senses and reason, which Alexander Gottlieb Baumgarten first set out in his Aesthetica of 1750. Presenting aesthetics as the "science of improving sensible cognition," Baumgarten sought to put sensory perception on a par with cognitive sciences. Baumgarten described sensory perception as analogon rationis. In Heinz Paetzold's view this meant that the "world- and ego-related modes of experience" that are possible through the senses now had a rationalism of their own, which corresponded to the "discursive rationale of 'pure' thinking in concepts."

But Eisenman dismantled the parallelism of senses and reason inherited from Baumgarten. In ornamental, labyrinthine-grotesqueries, the Dionysian is no longer pitted against the Apollonian, nor is cognitive comprehension pitted against sensory experience any more, for, by dint of the processes he developed, one thing arises from the last and always relates in a critically-reflective manner to its own origins. Sensory experience thus no longer comes about without critical reference to the rational processuality that preceded it. With criticalperformative reservations, we could say, as Nelson Goodman has put it, that "in aesthetic experience the emotions function cognitively" ${ }^{17}$ in that the former have already informed the latter. While there have hitherto been reasons to see art as a counterpart to the technological universe, since Eisenman's critical performativity there are now good reasons to not separate the two any longer.

With his automated, ecstatic processuality, Eisenman has done away with the parallelism of senses and reason that had lingered on since the Enlightenment. As though performing a double negation, Eisenman has set out "to reverse through." 18 Here on the margins of reason and in an excess of rationality, architecture becomes a "vehicle for critical awareness." All at once Eisenman's critique of reason turns into a praxis of epistemology. 
On this, see Roland Barthes, "La Mort de L'Auteur," in Essais Critiques IV, Le Bruissement de la Langue (Paris: 1984), 61-67. Philosophie in May 1978; "What is Critique?" trans. Lysa Hochroth, in The Politics of Truth, ed. Sylvère Lotringer (New York: 1997). Good Books," $A+U$ (1988):2.

Friedrich Nietzsche, Ecce Homo, trans. Duncan Large (Oxford :2009), 7.

Letter of 6 January 1889 to Jacob Burckhardt in Selected Letters of Friedrich Nietzsche, ed. and trans. Christopher Middleton (Chicago: 1969), 347. Peter Eisenman, "The End of the Classical: The End of the Beginning, the End of the End," Perpsecta 21 (1984): 154-73. Peter Eisenman in an interview in Vanity Fair, 1/1991. On this, see Peter Eisenman, "Transformations, Decompositions, and Critiques: House X," $A+U$, 80:01, 25-151. 
Trans. from Christoph Menke, Die Souveränität der Kunst (Frankfurt am Main: 1991), 10. Michel de Montaigne, On Friendship, trans. M. A. Screech (London: 2004), 1.

"una spezie di pittura licenziose e ridicole molto": Giorgio Vasari, Le Vite de piú eccellenti pittori scultori architetti italiani, Introduction, chapter 27: "Come si lavorino le grottesche su lo stucco," trans. by Louisa S. Maclehose, in Vasari on Technique (London: 1907), 245.

Theodor W. Adorno, Aesthetic Theory, ed. Gretel Adorno and Rolf Tiedeman, trans. Robert HullotKentor (London and New York: 1997), 47.

Manfredo Tafuri, "Les Bijoux indiscrets," in Five architects N.Y., ed. Manfredo Tafuri (Naples: 1981), 10.

Friedrich Nietzsche, Human, All Too Human, trans. R. J. Hollingdale (Cambridge: 1986), Aphorism 218, p. 178.

Heinz Paetzold, "Rhetorik-Kritik und Theorie der Künste in der philosophischen Ästhetik von Baumgarten bis Kant," in Kritische Theorie des Ornaments, ed. Gérard Raulet and Burghart Schmidt (Vienna et al., 1993), 30.

Nelson Goodman, Languages of Art. An Approach to a Theory of Symbols (Indianapolis and Cambridge: 1976), 248.

Friedrich Nietzsche, Nachgelassene Fragmente Frühjahr - Sommer 1888, KSA 13, 16[32], 492; Available online in English in Nietszche's Last Notebooks, trans. by Daniel Fidel Ferrer, p. 169, at http://books.google.co.uk/books?id=8aANUbCezaEC\&pg=PA266\&lpg=PA266\&dq=Nietzsche+ Fragments $+1888 \&$ source=bl\&ots=SsbVASILQ5\&sig=3dS28BFiGZ0feVFoT 8 XurOMbfoU\&hl= en\&sa $=$ X\&ei $=2 \mathrm{KwpU} 4 \mathrm{v} 2 \mathrm{Co} 6 \mathrm{jhgf} \_54 \mathrm{G} 4 \mathrm{Bw} \& \mathrm{ved}=0 \mathrm{CFUQ6AEwBg} \# \mathrm{v}=$ snippet\&q=experiment al\%20philosophy\&f=false

Barthes, Roland. "La Mort de L'Auteur.” in Essais Critiques IV, Le Bruissement de la Langue. Paris: 1984.

Foucault, Michel. "What is Critique?" In The Politics of Truth, edited by Sylvère Lotringer, translated by trans. Lysa Hochroth, New York: 1997.

Derrida, Jacques. "Why Peter Eisenman Writes Such Good Books." $A+U$ (1988): 2.

Nietzsche, Friedrich. Ecce Homo. Translated by Duncan Large. Oxford: 2009.

Nietzsche, Friedrich. Selected Letters of Friedrich Nietzsche. Edited and translated by Christopher Middleton. Chicago: 1969.

Eisenman, Peter. "The End of the Classical: The End of the Beginning, the End of the End." Perspecta 21 (1984).

Eisenman, Peter. "Transformations, Decompositions, and Critiques: House X." $A+U$, 80:01

Horkheimer, Max and Theodor W. Adorno. Dialectic of Enlightenment: Philosophical Fragments. Translated by Edmund Jephcott. Stanford University Press: 2007.

Menke, Christoph. Die Souveränität der Kunst. Frankfurt am Main: 1991.

Montaigne, Michel de. On Friendship. Translated by M. A. Screech. London: 2004. 
Vasari, Giorgio. Le Vite de 'piú eccellenti pittori scultori architetti italiani, Introduction, chapter 27: "Come si lavorino le grottesche su lo stucco." Translated by Louisa S. Maclehose, 245, in Vasari on Technique. London: 1907.

Adorno, Theodor W. Aesthetic Theory. Edited by Gretel Adorno and Rolf Tiedeman, translated by Robert Hullot-Kentor. London and New York: 1997.

Tafuri, Manfredo. "Les Bijoux indiscrets." In Five architects N.Y., edited by Manfredo Tafuri. Naples: 1981.

Nietzsche, Friedrich. Human, All Too Human. Translated by R. J. Hollingdale. Cambridge: 1986. Paetzold, Heinz. "Rhetorik-Kritik und Theorie der Künste in der philosophischen Ästhetik von Baumgarten bis Kant." In Kritische Theorie des Ornaments. Edited by Gérard Raulet and Burghart Schmidt. Vienna et al., 1993.

Goodman, Nelson. Languages of Art. An Approach to a Theory of Symbols. Indianapolis and Cambridge: 1976. 


\section{PITER AJZENMAN,}

\section{ILI KAKO ELIMINISATI ONO ŠTO ČOVEK POSTANE}

\section{Jörg H. Gleiter}

Piter Ajzenman je Ikar post-avangardne arhitekture koji se može pohvaliti brojnim visoko cenjenim, kontroverznim objektima - kao što su Spomenik ubijenim Jevrejima Evrope u Berlinu i Ciudad de la Cultura de Galicia u Santijagu de Kompostela. Kako eliminisati ono što čovek postane-ovo je jedan od načina da se rezimira jedna od presudnih odlika Ajzenmanove arhitektonske prakse: nestanak autora. Pokazujući svoj prezir prema individualnom stilu u umetnosti, Ajzenman je u debatama o arhitekturi redovno potezao pitanje Mišela Fukoa: „Šta je pisac?” Međutim, smrt autora - „la mort de l'auteur” koju je prvi put pomenuo Roland Bart - nije bila sama sebi svrha po Ajzenmanu. Zato što jedino pitanje koje sledi:,Šta je kritika?”, osvetljava ulogu eliminacije autora u negativnosti estetike Ajzenmanove arhitektonske prakse: to je dijalektika kritike razuma i epistemologije. U tom smislu, Ajzenmanova teorija arhitekture predstavlja važan-ako ne nekontroverzan-doprinos kritičkoj filozofiji arhitekture.

KLJUČNE REČI: PITER AJZENMAN, FILOZOFIJA ARHITEKTURE, KRITIČKA TEORIJA, AUTORSTVO, DEKONSTRUKCIJA, PROJEKTOVANJE

OPERATIVNE RAZLIKE.

\section{AJZENMAN, TAFURI I LEKCIJA PIRANEZIJA}

\section{Gabriele Mastrigli, Alessandro Toti}

Piter Ajzenman je arhitekta. Iako povezana sa interesovanjem za razne oblike, oblast njegovog delovanja obuhvata istraživanje teorijskog osnova arhitektonske discipline. Arhitektura, kao artefakt i kao projekat, može da se posmatra kao najočiglednija reprezentacija tradicionalne opozicije zapadne metafizike: odsustva i prisustva. Stoga je zadatak arhitekte, prema Ajzenmanu, da analitički interveniše u ovom dijalektičkom stanju i učini ga operativnim.

Sa ove tačke gledišta, Ajzenmanov pristup disciplini - kao i čitav njegov, celoživotni arhitektonski razvojni put - posmatra se u svetlu dela Đovanija Batiste Piranezija. Otišavši dalje od kritike italijanskog istoričara arhitekture Manfreda Tafurija, Ajzenman je istraživao mogućnost novog tumačenja dijalektike između pozitivnog i negativnog, izbravši pojam zemljišta kao samog mesta ove opozicije. Berlinski Spomenik ubijenim Jevrejima Evrope nudi konačnu reprezentaciju ove dijalektike, čime otvara mogućnost daljeg, neuporedivog rada na njoj.

KLJUČNE REČI: ARHITEKTURA, RAZLIKE, ANALIZA, PROJEKAT, DIJALEKTIKA, REPREZENTACIJA, JEZIK, MONTAŽA, TRAG, ZEMLJIŠTE, SUBJEKT. 
DIGITALNO :

OD KOMPLEKSNOSTI DO JEDNOSTAVNOSTI - I NATRAG

\section{Mario Carpo}

Na početku digitalnog prevrata u ranim 90-tim godinama, digitalno inteligentna arhitektura je uopšteno smatrana krivolinijskom, oblom i modernom. Zašto? Računari su izuzetno svestrane mašine, ali koje ne pokazuju estetičke preferencije. Svakako da Piter Ajzenman, koji je jedan od izumitelja digitalizovanog pravca i 90-tim, nije imao ovo na umu. I zašto se danas stil/pravac digitalno inteligentne arhitekture ponovo menja?

Ovo su (neka od) pitanja koja su obrađena u ovom kratkom radu koji ispituje zašto i kako digitalno kao alat uključuje, ovladava i proizvodi kompleksnost.

KLJUČNE REČI: DIGITALNO, SPLAJNOVI / KRIVE, ALAT, KOMPLEKSNOST, AJZENMAN

\section{ŠTA JE ARHITEKTONSKO ISTRAŽIVANJE DANAS \\ I GDE JE OSNOV?}

\section{Djordje Stojanović}

Zašto graditi velike objekte od gumica sa studentima arhitekture? Na koji način je taj poduhvat povezan sa arhitektonskim obrazovanjem? I ako objekti od gumica nisu ni zgrade, ni modeli, već neka vrsta eksperimenata, kakvu vrstu znanja relevantnog za građevinsku industriju i izgrađeno okruženje oni generišu? Ovo su neka od pitanja koja su postavljena na konferenciji "ISSUES? Concerning the projects of Peter Eisenman" /PITANJA? U vezi sa projektima Pitera Ajzenmana/ koja je održana u Beogradu, u novembru 2013. Ona su povezana sa nizom projektantskih istraživačkih projekata koji su nedavno završeni na Arhitektonskom fakultetu, Univerziteta u Beogradu, i koji su dokumentovani u tematskom izdanju Srpskog arhitektnoskog žurnala pod naslovom „Arhitektonsko obrazovanje u postdigitalnom dobu” koje je objavljeno nezavisno od, ali skoro istovremeno sa održavanjem konferencije. U skladu sa argumentima iznetim u toj publikaciji, ovaj rad će prikazati neke od relevantnih i opšteprihvaćenih teorija i manifesta koji se odnose na metodologije projektantskog istraživanja, pružajući osnov za tekući rad na Arhitektonskom fakultetu, Univerziteta u Beogradu.

KLJUČNE REČI: ARHITEKTONSKO ISTRAŽIVANJE, UMETNIČKO ISTRAŽIVANJE, ISTRAŽIVANJE KROZ PROJEKAT, ISTRAŽIVANJE ZASNOVANO NA PRAKSI 